\title{
Knowledge, attitudes and practices of nurses and doctors about the vertical transmission of hepatitis $B^{1}$
}

Isabela Cristina de Miranda Gonçalves²

Maria Jacirema Ferreira Gonçalves ${ }^{3}$

Objective: to identify knowledge, attitudes and practices of physicians and nurses of the Family Health Strategy and a maternity hospital unit about vertical transmission of hepatitis B. Method: a cross-sectional study with a self-administered questionnaire applied to professionals. The data were analyzed according to professional category and site of action, whose differences were tested by $\chi^{2}$ and significance $<5 \%$. Results: professionals recognize viral hepatitis as a disease of compulsory notification; however, not everyone knows its mechanisms of transmission. A large portion of professionals requested serological tests, specifying the marker, especially physicians. The majority of family health nurses did not indicate hepatitis B vaccine for pregnant women, although they knew the immunization schedule. The majority of physicians on the maternity unit had proper knowledge about prevention of vertical transmission. Conclusion: the differences in the knowledge, attitudes and practices about vertical transmission of hepatitis $B$ revealed that the population is at risk, since not all the professionals involved know or properly perform control strategies for vertical transmission of hepatitis B. Nurses dominated vaccination aspects and physicians dominated aspects related to the management of cases with positive serology.

Descriptors: Health Knowledge, Attitudes, Practice; Infectious Disease Transmission, Vertical; Hepatitis B; Health Personnel.

\footnotetext{
${ }^{1}$ Paper extracted from master's thesis "Conhecimentos, atitudes e praticas de profissionais da saúde frente à transmissão vertical da hepatite B", presented to Universidade Federal do Amazonas, Manaus, AM, Brazil.

${ }^{2}$ MSc, Assistant Professor, Universidade do Estado do Amazonas, Manaus, AM, Brazil.

${ }^{3}$ PhD, Researcher, Instituto Leônidas e Maria Deane (FIOCRUZ), Manaus, AM, Brazil. Adjunct Professor, Universidade Federal do Amazonas, Manaus, AM, Brazil.
} 


\section{Introduction}

Hepatitis B is a potentially fatal infection caused by the hepatitis $B$ virus. It is a global health problem and the most serious type among the viral hepatitis infections(1). One strategy for detection of the virus is screening in every pregnant woman during the prenatal period for the surface antigen of viral hepatitis B - HBsAg, in order to prevent the vertical transmission of the virus ${ }^{(2-3)}$.

In Brazil, 1,556 confirmed cases of hepatitis B in pregnant women were reported in 2009, corresponding to a detection rate of $0.5 / 1,000$ live births. In that same year, the midwestern region had the highest detection rate in the country, with 313 notifications $(1.5 / 1,000$ live births). Sequential rates encountered included: southern region (452 notifications or $1.2 / 1,000$ live births), northern region (235 cases or $0.8 / 1,000$ live births), southeastern region (392 cases or $0.3 / 1,000$ live births) and northeastern region (161 cases or $0.2 / 1,000$ live births). Meanwhile, data from vertical transmission of hepatitis B, as a probable source of infection, which is still incipient in the country, reflecting the structuring of the surveillance system, but even so, the country registered an increased detection of seven cases (1.5\%) in 1999 to 285 cases (2.2\%) in 2006(4).

Studies have shown that the reduction of maternal and perinatal morbidity and mortality depends on the investment and restructuring of assistance to pregnant women and newborns, in order to improve quality, and the formation and training of physicians and other health professionals to promote safe motherhood(5-6). For this, health professionals must have acquired competencies, not only with training but also with practice, enabling proper management, both of the pregnancy, labor and delivery, and care of newborns, including aspects relating to prevention of vertical transmission of hepatitis $B$.

In 2005, research conducted in Brazil to identify the knowledge of obstetricians about the detection of infection of the hepatitis B virus in pregnant women, and forms of prevention of vertical transmission of hepatitis $B$, identified knowledge below expectations ${ }^{(7)}$. Meanwhile, other national studies have not been identified on the theme, with a focus on nursing. International research points to deficient knowledge, attitude and practice of health professionals about infection by the hepatitis $B$ virus ${ }^{(8)}$. On the other hand, another study identified a high knowledge of obstetricians and gynecologists about preventing infectious diseases, including hepatitis $B$, in pregnancy ${ }^{(9)}$.

The current work aimed to identify the knowledge, attitudes and practices of physicians and nurses of the
Family Health Strategy and a public maternity hospital, faced with the vertical transmission of hepatitis $B$.

\section{Method}

This was an epidemiological, cross-sectional, quantitative study, conducted using primary data, collected through a self-administered questionnaire, applied to physicians and nurses to identify competence. The concept of the term competence was based on three dimensions: knowledge, attitudes and practices ${ }^{(10-11)}$.

The research was conducted in a maternity hospital and in 46 Family Health Teams located in the Western Health District of the city of Manaus, capital of the Amazonas state. The following inclusion criteria of professionals used were: a minimum of one year since graduation and working for at least one year in the service; a physician or nurse with registration in the Cadastro Nacional de Estabelecimentos de Saúde (National Register of Health Facilities) as a professional locus of the research .

The questionnaire was evaluated by 15 experts on the subject. The achievement of face and content validity was sought ${ }^{(12-13)}$. The data collection instrument was divided in three blocks: the first corresponded to individual characteristics, in which the sociodemographic aspects, completion of education or qualification for viral hepatitis and whether it met their needs were investigated; in the second block the knowledge variables were concentrated; and, the third block included the attitudes and practice variables regarding the diagnosis of hepatitis $B$ and prevention of vertical transmission of the virus. Figure 1 shows in detail the variables of the second and third blocks of the questionnaire.

After adapting the instrument to the opinions of experts, a pre-test to verify the performance of the instrument, with professionals from a maternity unit and the Family Health Strategy (FHS), in another Health District who were not part of this sample. Data collection occurred in the period from July to September of 2010, in which the questionnaire was administered to all professionals who met the inclusion criteria.

The approach to the professionals of the ESF occurred in their workplace (in the health unit, at the time of delivery of the weekly production in the district headquarters of health, or in the district meeting). After the sensitization and obtaining of consent for the research, by signing the terms of free and informed consent (TFIC), the questionnaire was given to the professional. We awaited the return of the completed questionnaire, and 
when the professional could not respond immediately, there was a subsequent search, a date and place indicated by the professional, the closest possible to the date of the first approach. Professionals of maternity unit were visited during their work day, on the premises of the unit. In order to reduce the number of losses, including in the FHS, different approaches to the return of questionnaires were used: seeking respondents at the end of a shift, the next shift or in another workplace indicated by the professionals. The mean waiting time for return of the completed questionnaire by the participants of the FHS and maternity unit was five days. The questionnaire was considered a loss when the professional was not located after three attempts, was laid off, or refused to participate.

The questionnaires were entered in the EpiInfo software version 3.5.1, and the database was exported for analysis in the STATA program, version 9.0. To analyze the results, criteria were established to consider the knowledge, attitudes and practices for hepatitis $B$ and its vertical transmission as correct, incorrect and partially correct, Figure 1 . These criteria were established according to the current standard recommended by the Ministry of Health in Brazil.

The characterization of professionals and categories of adequacy of knowledge, attitudes and practices were presented by means of frequency and percentage, according to the professional category (physicians and nurses) and workplace (Family Health Strategy and maternity hospital unit). When appropriate, the Pearson or Fisher chi-square test was applied to test the differences between professional categories and the workplace. A value of less than $5 \%$ was used as the level of significance.

The research project was approved by the Committee on Ethics in Research involving Human Beings, Universidade Federal do Amazonas (Federal University of Amazonas - CAAE), number 0026.0.115.000-10.

\begin{tabular}{|c|c|c|c|}
\hline Questions and responses related to knowledge & Correct & Partially correct & Incorrect \\
\hline Hepatitis - Disease of compulsory notification & Yes & - & No \\
\hline Mechanisms of HBV transmission* & $\begin{array}{l}\text { Sexual, parenteral } \\
\text { and vertical }\end{array}$ & $\begin{array}{l}\text { Two of the forms: sexual, } \\
\text { parenteral, or vertical }\end{array}$ & $\begin{array}{l}\text { Sexual or parenteral or } \\
\text { vertical }\end{array}$ \\
\hline Mechanisms of HDV transmission ${ }^{\dagger}$ & $\begin{array}{l}\text { Sexual, parenteral } \\
\text { and vertical }\end{array}$ & $\begin{array}{l}\text { Two of the forms: sexual, } \\
\text { parenteral, or vertical }\end{array}$ & $\begin{array}{l}\text { Sexual or parenteral or } \\
\text { vertical }\end{array}$ \\
\hline Condition adjuvant to having HDV & Being a carrier of HBV & - & Any other option \\
\hline Immunization schedule & 3 doses $-0,1 \& 6$ months & - & Any other option \\
\hline Performs preventive practice in $\mathrm{NB}^{\ddagger}$ & Yes & - & No \\
\hline Questions and Responses about Attitudes and Practices & Correct & Partially correct & Incorrect \\
\hline Need for testing for disease transmission in prenatal period & Yes & - & No \\
\hline $\begin{array}{l}\text { Requests test for vertical transmission of the disease in prenatal } \\
\text { period }\end{array}$ & Yes & - & No \\
\hline Which diseases should be investigated & HIV§, syphilis, Toxo", HBV & - & Any other option \\
\hline Requests for HBV serology specifying the marker & Yes & - & No \\
\hline $\begin{array}{l}\text { Which marker is requested to investigate HBV during prenatal } \\
\text { care }\end{array}$ & $\mathrm{HBsAg}^{* *}$ & - & Any other option \\
\hline $\begin{array}{l}\text { Indicates hepatitis B vaccine in pregnant women without } \\
\text { previous contact }\end{array}$ & Yes & - & No \\
\hline Prevention of vertical transmission in infants & $\begin{array}{l}\text { Immunoglobulin, vaccine for } \\
\text { Hepatitis B and reference }\end{array}$ & $\begin{array}{l}\text { Immunoglobulin and } \\
\text { vaccine for Hepatitis B }\end{array}$ & Any other option \\
\hline Confirmatory marker of immunity after vaccination of NB & Anti-HBs ${ }^{\dagger+}$ & - & Any other option \\
\hline Uses handbook about viral hepatitis & Yes & - & No \\
\hline
\end{tabular}

*HBV: Hepatitis B virus. +VHD: Hepatitis D virus. ¥NB: newborn. §HIV: Human immunodeficiency virus. Toxol|: toxoplasmosis. **HBsAg: hepatitis B surface antigen. †+Anti-HBs: antibodies against the hepatitis B surface antigen

Source: organized by the authors, based on the Health Ministry ${ }^{(14-15)}$

Figure 1 - Classification of the adequacy of knowledge, attitudes and practices about the vertical transmission of hepatitis $B$

\section{Results}

This research included almost all of the physicians and nurses working in prenatal care, delivery and puerperium. In the maternity hospital unit, there were 49 nurses and 55 obstetricians, with the loss of five medical professionals, representing $4.8 \%$ of the population. Regarding the FHS, in the western district, 
there were 41 physicians and 46 nurses, with the loss of eight physicians and 11 nurses, equivalent to $8.0 \%$.

Table 1 shows the sociodemographic characteristics of the sample on the maternity unit and in the
FHS. Statistically significant differences appeared in relationship to the time after graduation and complementary education, which was higher for maternity unit professionals.

Table 1 - Distribution of the maternity professionals and the Family Health Strategy according to sociodemographic characteristics. Manaus, AM, Brazil, 2010

\begin{tabular}{|c|c|c|c|c|c|c|c|}
\hline \multirow{2}{*}{ Characteristics } & \multicolumn{2}{|c|}{ FHS* } & \multicolumn{2}{|c|}{ Maternity unit } & \multicolumn{2}{|c|}{ Total } & \multirow{2}{*}{$\begin{array}{c}\chi^{2} \\
\text { (p-value) }\end{array}$} \\
\hline & $n=68$ & $\%$ & $n=99$ & $\%$ & $n=167$ & $\%$ & \\
\hline \multicolumn{8}{|l|}{ Sex } \\
\hline Male & 20 & 29.4 & 25 & 25.3 & 45 & 26.9 & 0.354 \\
\hline Female & 48 & 70.6 & 74 & 74.7 & 122 & 73.1 & $(0.55)$ \\
\hline \multicolumn{8}{|l|}{ Age group (years) } \\
\hline$<30$ & 1 & 1.5 & 3 & 3.0 & 4 & 2.4 & 4.331 \\
\hline $30-39$ & 41 & 60.3 & 47 & 47.5 & 88 & 52.7 & $(0.36)$ \\
\hline $40-49$ & 16 & 23.5 & 28 & 28.3 & 44 & 26.3 & \\
\hline$\geq 50$ & 8 & 11.8 & 12 & 12.1 & 20 & 12.0 & \\
\hline Not reported & 2 & 2.9 & 9 & 9.1 & 11 & 6.6 & \\
\hline \multicolumn{8}{|l|}{ Time since graduation (years) } \\
\hline $1-5$ & 0 & 0.0 & 5 & 5.1 & 5 & 3.0 & 18.186 \\
\hline $5-9$ & 33 & 48.5 & 19 & 19.2 & 52 & 31.1 & $(<0.01)$ \\
\hline$\geq 10$ & 35 & 51.5 & 75 & 75.8 & 110 & 65.9 & \\
\hline \multicolumn{8}{|l|}{ Graduation } \\
\hline Medicine & 33 & 48.5 & 50 & 50.5 & 83 & 49.7 & 0.062 \\
\hline Nursing & 35 & 51.5 & 49 & 49.5 & 84 & 50.3 & $(0.80)$ \\
\hline \multicolumn{8}{|l|}{ Additional Education } \\
\hline None & 11 & 16.2 & 2 & 2.0 & 13 & 7.8 & 34.702 \\
\hline Residency & 3 & 4.4 & 43 & 43.4 & 46 & 27.5 & $(<0.01)$ \\
\hline Specialization & 54 & 79.4 & 66 & 66.7 & 120 & 71.9 & \\
\hline Postgraduate stricto sensu & 2 & 3.0 & 1 & 1.0 & 3 & 1.8 & \\
\hline
\end{tabular}

* Family Health Strategy. + It was possible to have more than one response for each professional (sum>100\%)

Considering that in primary care the low-risk prenatal ocurred, and not in the maternity unit, Table 2 shows the attitudes and practices answered only by FHS professionals, where a statistically significant difference was detected for serologic testing for hepatitis B specifying the marker, which occurs in greater proportion among the physicians. Although there was no statistically significant difference, it is noteworthy that almost $65 \%$ of professionals did not indicate hepatitis $B$ vaccine for pregnant women, of whom the majority were FHS nurses.

Table 2 - Responses from physicians and nurses of the Family Health Strategy regarding attitudes and practices against the transmission of hepatitis B. Manaus, AM, Brazil, 2010

\begin{tabular}{|c|c|c|c|c|c|c|c|}
\hline \multirow{3}{*}{ Attitudes and Practices } & \multicolumn{7}{|c|}{ Family Health Strategy } \\
\hline & \multicolumn{2}{|c|}{ Nurse } & \multicolumn{2}{|c|}{ Physician } & \multicolumn{2}{|c|}{ Total } & \multirow{2}{*}{$\begin{array}{c}\chi^{2} \\
(p-v a l u e)\end{array}$} \\
\hline & $n=35$ & $\%$ & $n=33$ & $\%$ & $n=68$ & $\%$ & \\
\hline \multicolumn{8}{|c|}{ Need for testing for disease transmission in prenatal care } \\
\hline Incorrect & 1 & 2.9 & 0 & 0.0 & 1 & 1.5 & 0.956 \\
\hline Correct & 34 & 97.1 & 33 & 100.0 & 67 & 98.5 & $(1.00)^{*}$ \\
\hline \multicolumn{8}{|c|}{$\begin{array}{l}\text { Requests test of vertical disease transmission in } \\
\text { prenatal care }\end{array}$} \\
\hline Incorrect & 1 & 2.9 & 0 & 0.0 & 1 & 1.5 & 0.956 \\
\hline Correct & 34 & 97.1 & 33 & 100.0 & 67 & 98.5 & $(1.00)^{*}$ \\
\hline
\end{tabular}


Table 2 - (continuation)

\begin{tabular}{|c|c|c|c|c|c|c|c|}
\hline \multirow{3}{*}{ Attitudes and Practices } & \multicolumn{7}{|c|}{ Family Health Strategy } \\
\hline & \multicolumn{2}{|c|}{ Nurse } & \multicolumn{2}{|c|}{ Physician } & \multicolumn{2}{|c|}{ Total } & \multirow{2}{*}{$\begin{array}{c}\chi^{2} \\
\text { (p-value) }\end{array}$} \\
\hline & $\mathrm{n}=35$ & $\%$ & $n=33$ & $\%$ & $n=68$ & $\%$ & \\
\hline \multicolumn{8}{|l|}{ Which diseases are investigated } \\
\hline Incorrect & 1 & 2.9 & 0 & 0.0 & 1 & 1.5 & 1.142 \\
\hline Partially correct & 3 & 8.6 & 2 & 6.1 & 5 & 7.4 & $(1.00)$ \\
\hline Correct & 31 & 88.6 & 31 & 93.9 & 62 & 91.2 & \\
\hline \multicolumn{8}{|c|}{ Requests HBV serology specifying the marker } \\
\hline Incorrect & 14 & 40.0 & 5 & 15.2 & 19 & 27.9 & 5.208 \\
\hline Correct & 21 & 60.0 & 28 & 84.8 & 49 & 72.1 & $(0.02)$ \\
\hline \multicolumn{8}{|c|}{$\begin{array}{l}\text { What marker is requested to investigate HBV in } \\
\text { prenatal care }\end{array}$} \\
\hline Incorrect & 4 & 19.0 & 5 & 17.9 & 9 & 18.4 & 0.011 \\
\hline Correct & 17 & 81.0 & 23 & 82.1 & 40 & 81.6 & $(0.91)$ \\
\hline \multicolumn{8}{|c|}{$\begin{array}{l}\text { Indicates hepatitis B vaccine in pregnant women } \\
\text { without previous contact }\end{array}$} \\
\hline Incorrect & 26 & 74.3 & 18 & 54.5 & 44 & 64.7 & 2.898 \\
\hline Correct & 9 & 25.7 & 15 & 45.5 & 24 & 35.3 & $(0.08)$ \\
\hline
\end{tabular}

*Fisher's exact test. TThe number does not correspond to the total, because it was answered only by those who marked that they would request serology for hepatitis B specifying the marker

Table 3 presents the knowledge about the mechanisms of transmission of hepatitis $B$ and $D$, the vaccine schedule and practice for prevention in the newborn. The correct knowledge on the part of physicians from the maternity unit stood out for the mechanisms of transmission of hepatitis $B$ and $D$. Regarding the immunization schedule for hepatitis $B$, the nurses, in both study locations, performed better. However, when stratified by locus of action, the FHS excelled.

Table 4 shows the attitudes and practices of professionals related to the prevention of vertical transmission of hepatitis B. It is emphasized that care for the newborns of mothers with positive serology for hepatitis $B$ is best developed by the physicians of the maternity unit. Opposed to this is the inadequate conduct of the nurses in the FHS in the solicitation of the marker to confirm immunity after vaccination of newborns. Of the 167 respondents, only 59 (35.3\%) reported their use of the manual of the Ministry of Health in the service, with approaches for viral hepatitis. However, of those who said they used the manual, only 32 (55.9\%) reported that it met the needs of the service. 


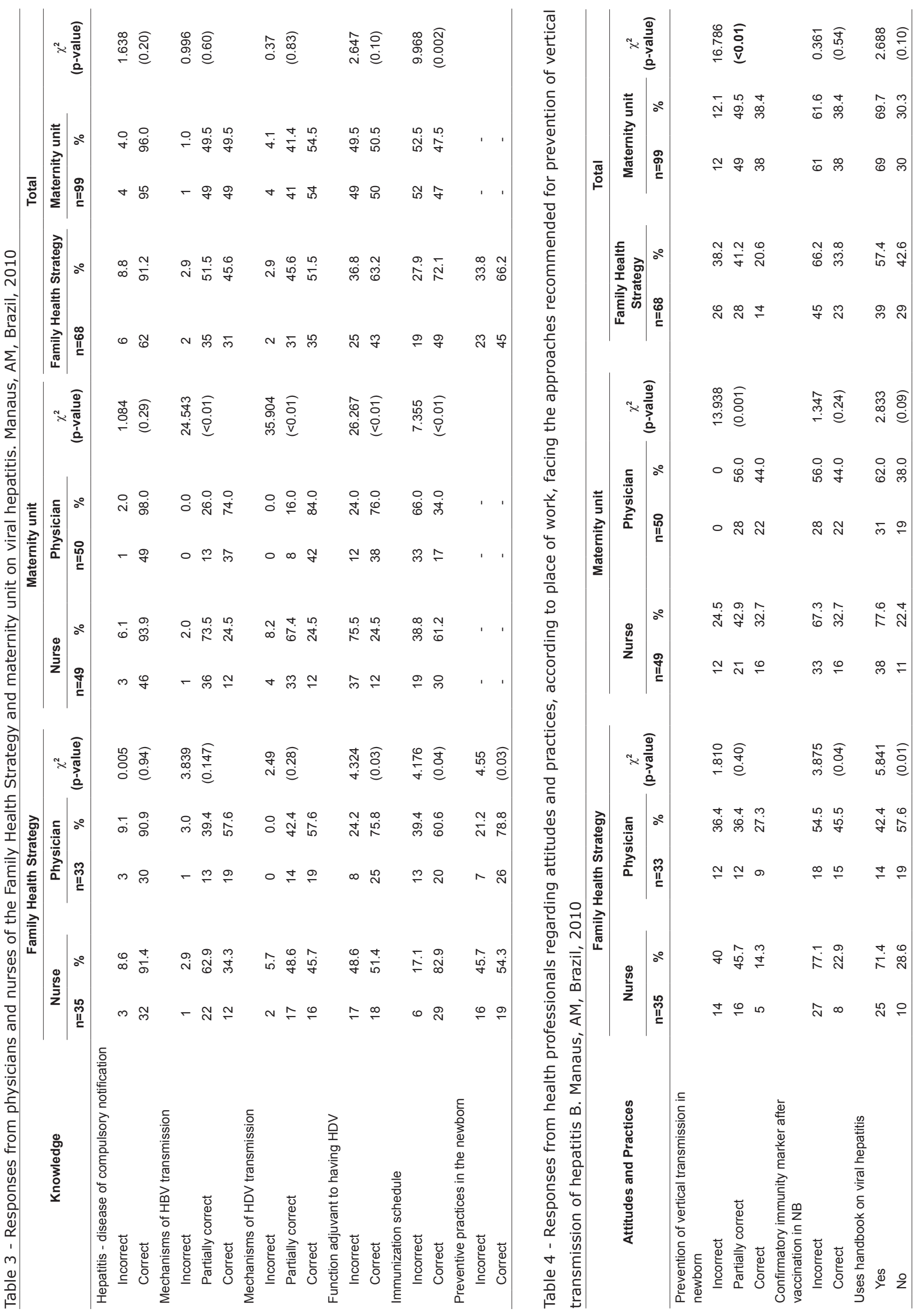




\section{Discussion}

This research made it possible to detect the state of knowledge, attitudes and practices of physicians and nurses involved in the treatment and prevention of vertical transmission of hepatitis B. Important differences were detected both among professionals (physicians and nurses), and between workplaces (maternity unit and Family Health Strategy). Such results draw attention, because if the management of the pregnant woman is not adequate, we cannot control the vertical transmission, which, if transmitted to the newborn, greatly increases the potential for chronicity of this important public health problem in Brazil, which is hepatitis $B$.

The analysis of the profile of the professionals showed young adults, with a mean of 39.8 years of age (standard deviation $=7.5$ ). Age can be an approximation of professional experience, although many people can graduate at an older age. We are not saying that experience itself is a predictor of knowledge, attitudes and adequate practices, but that it indicates whether the professional has had more opportunity to confront the problem and/or receive training in service. Added to the finding, a study that examined the care practices of physicians and nurses of the Family Health Teams in four capitals, showed no significant association between time working and routine activities developed by physicians and nurses in primary care ${ }^{(16)}$.

A study that examined the exercise of competence of non-physicians for maternity care, in São Paulo, found that $42 \%$ of professionals reported difficulties in operationalizing the care of pregnant and postpartum women, due to lack of knowledge, skills or training. The author assigned the deficient care provided to the fact that many had failed to keep up with advances and changes in labor care instituted by the Ministry of Health $(\mathrm{MOH})$ for humanized and evidence-based care $^{(17)}$. Similar results were found with the sample of this research, in which maternity professionals had more time since graduation, but had completed fewer complementary educational programs compared to those in the FHS.

It is desirable that health care services prepare their professionals for work in their respective area of action. Thus, the availability of the offered information can be guaranteed and provide the server with the basic instruments of action, among them, knowledge. The present research captured little performance of training sessions, as mentioned by the professionals; although, it is believed that it is not enough to train a group of professionals to ensure better care in prenatal care, labor and puerperium. It is necessary that they feel incentivized and mobilized to rethink their behavior in response to daily practice. But the feeling of insecurity in relation to the daily work of a professional can arise on account of one's technical scientific outdating.

A study comparing the professional specialists with generalists observed that the former, treating patients with diagnoses within the scope of their specialty, are generally regarded as those who provide better quality care to these problems than the primary care professionals (general)(18). However, the outcomes of this study do not enable the corroboration of such inference. In comparison of professional category, the nurse stood out in terms of knowledge of the immunization schedule for pregnant women, but the attitudes and practices of care for the newborn of the mother who is a carrier of hepatitis B were more correct among physicians. Therefore, strategies must be created to address the imbalance between knowledge, attitudes and the practices of professionals. One possibility for mitigating this gap would be the use of the $\mathrm{MOH}$ manuals by professionals, in order that they could contribute to knowledge, attitudes and adequate practices.

One of the elements that contributes to the prevention of vertical transmission of hepatitis $B$ was knowledge and compliance with the established actions for prevention, which depended mainly on the attitudes and practices of the professionals. This consisted of both identifying how much to approach the professionals in terms of the importance of prenatal care in interrupting the chain of transmission of the hepatitis B virus, in addition to the competencies that they maintain as health professionals involved in prenatal care and childbirth. These professionals are strategic actors in the construction and transmission of information, and the development of preventive measures and control of hepatitis B for the population. However, it is necessary to expand the awareness of professionals to the problem of vertical transmission of hepatitis $B$, and assumption of their responsibilities, executed in an interdisciplinary manner, since they act on the same target. Therefore, interpersonal dialogue, sharing of registration of the patients in the medical records, among professionals, may constitute a short-term measure to minimize the problem. The differences between the workplaces could already be solved with the adequate functioning of integrality, through the coordination of care ${ }^{(18)}$. So we would have an approximate dialogue between the 
FHS and maternity unit, and integrated monitoring of pregnant women.

Unfortunately, this is not an exclusive reality of Amazon, since, in an analysis for Brazil as a whole, a differentiation was justified in the degree of information about hepatitis B among health professionals, due to regional inequalities in the incidence and prevalence of this disease in the country(7).

Due to the change in the recommendation of immunprophylaxis, regardless of age range, for all pregnant women that was formalized in March 2010, it is believed that the lack of this information has provided an inadequate attitude and practice of not indicating vaccination for this target public ${ }^{(19)}$. The wrong practices hinder the effectiveness of programs to prevent vertical transmission of hepatitis B. Only an adequate surveillance system, professional development, training, continuing in-service education, and compliance with clearly established protocols can guarantee the prevention of vertical transmission of hepatitis $B$.

It is necessary to point out the necessary revision and correction of practices found to be inadequate in this study, which are used by professionals during labor and delivery and/or the puerperium, due to ignorance of the protocols, which was also detected in the study in which obstetricians and gynecologists of Campinas presented low knowledge and inadequate attitudes about syphilis in pregnancy(20). The articulation of knowledge and practice must be combined and confronted, in order to construct a true praxis in health care(21).

Some limitations were detected, but it was considered that they did not essentially compromise the results presented here. Noteworthy is the type of data collection, in which return of the questionnaire was based on the convenience of the participant, not allowing the restriction of consultation by professionals for completing it. Thus, considering that the results presented here could overestimate the state of knowledge, attitudes and practices, due to the possibility of consultation to answer the questionnaire, perhaps the knowledge, attitudes and practices are much more deficient than the results presented, a situation that compromises control strategies of vertical transmission of hepatitis $B$.

Another limiting factor was the quantification of the variables of knowledge, attitudes and practices instead of on-site observation of the practices of professionals. However, the approach to the topic, from the pattern determined by the Ministry of Health allowed the research. However, further research with a qualitative approachis recommended in order to validate if the attitudes and practices of professionals are indeed reflective of their knowledge.

Therefore, the results serve as a warning to the operational issue of primary care, as well as the ability of professionals dealing with possible demands. A study that analyzed the professional trajectory of graduates of specialization courses in Family Health emphasized that competence was related to the ability to resolve problems when facing given situations, skills, attitudes and coping with unpredictable situations. Moreover, in this study, it was revealed that the graduates resisted general practice and had difficulty putting into practice actions consistent with the Family Health Strategy(22).

Furthermore health professionals need to internalize the importance of sharing knowledge, through communities of practice, guidelines, manuals, and the use of these in care practice ${ }^{(23)}$. In this study it was possible to corroborate these findings, since the results innovate to identify the differences between physicians and nurses and the site of action for certain care practices. Thus, the article adds evidence to other studies, contributing to the strengthening of the care practices developed.

\section{Conclusion}

The research revealed inequities in knowledge, attitudes and practices about the vertical transmission of hepatitis B among physicians and nurses of the maternity unit and the Family Health Strategy. This calls attention to the risk to which the population is exposed, since not all professionals knew or correctly performed the control strategies for vertical transmission of the virus, with the nurses having the mastery of aspects of vaccination, and the physicians having those related to management of cases with positive serology.

The lack of knowledge and inadequate attitudes and practices in the diagnosis and prevention of the disease revealed the need for ongoing training of professionals involved in prenatal, delivery and postpartum care. Therefore, it is necessary to disseminate the skills of physicians and nurses, in order to achieve integrality, through the coordination of care for the pregnant and postpartum carrier of hepatitis $B$.

By presenting the weaknesses and strengths of the care provided by the professionals in primary care and maternity when facing vertical transmission of hepatitis $B$, it is expected that this study will trigger concerns about the issue in order to alert physicians, nurses and the public powers about the need for more attention to 
measures for the diagnosis and prevention of hepatitis $B$ virus and its vertical transmission.

\section{References}

1. World Health Organization. Hepatitis B. 2012. [acesso 3 abr 2013]. Disponível em: http://wwwwhoint/ mediacentre/factsheets/fs204/en/indexhtml.

2. Chakravarti A, Rawat D, Jain M. A Study on the Perinatal Transmission of the Hepatitis B Virus. Indian J Med Microbiol. 2005;23(2):128-30.

3. Center for Disease Control and Prevention (USA). Hepatitis B Information for Health Professionals, 2013. [acesso 26 abr 2013]. Disponível em: http://www.cdc. gov/hepatitis/HBV/PerinatalXmtn.htm

4. Ministério da Saúde (BR). Estudo de base populacional das hepatites virais. Disponível em: http://www.aids. gov.br/data/Pages. Brasília; 2010.

5. Lansky S, França E, Leal MC. Mortalidade perinatal e evitabilidade: revisäo da literatura. Rev Saúde Pública. 2002;36(6):759-72.

6. Reekie J, Gidding HF, Kaldor JM, Liu B. Country of birth and other factors associated with hepatitis B prevalence in a population with high levels of immigration. J Gastroenterol Hepatol. 2013. Forthcoming.

7. Conceição JS, Diniz-Santos DR, Ferreira CD, Paes FN, Melo CN, Silva LR. Conhecimento dos obstetras sobre a transmissão vertical da hepatite B. Arq Gastroenterol. 2009;46(1):57-61.

8. Bakry SH, Mustafa AF, Eldalo AS, Yousif MA. Knowledge, attitude and practice of health care workers toward Hepatitis B virus infection, Sudan. Int J Risk Saf Med. 2012;24(2):95-102.

9. Ross DS, Rasmussen SA, Cannon MJ, Anderson B, Kilker K, Tumpey A, et al. Obstetrician/gynecologists' knowledge, attitudes, and practices regarding prevention of infections in pregnancy. J Womens Health (Larchmt). 2009;18(8):1187-93.

10. Marinho LAB, Costa-Gurgel MS, Cecatti JG, Osis MJD. Conhecimento, atitude e prática do auto-exame das mamas em centros de saúde. Rev Saúde Pública. 2003;37(5):576-82.

11. Leme R. Avaliação de desempenho com foco em competências: a base para remuneração por competências. Rio de Janeiro: Qualitymark; 2006.

12. Lobiondo-Wood G, Haber J. Confiabilidade e validade. In: Lobiondo-Wood G, Haber J, organizadores. Pesquisa em enfermagem: métodos, avaliação crítica e utilização. $3^{a}$ ed. Rio de Janeiro: Editora Guanabara Koogan; 2001. p. 186-99.
13. Terwee $C B$, Bot SD, Boer MR, Windt DA, Knol DL, Dekker J, et al. Quality criteria were proposed for measurement properties of health status questionnaires. J Clin Epidemiol. 2007;60(1):34-42.

14. Ministério da Saúde (BR). Pré-natal e Puerpério: atenção qualificada e humanizada - manual técnico. Brasília; 2006.

15. Ministério da Saúde (BR). Secretaria de Vigilância em Saúde. Departamento de Vigilância E. Guia de vigilância epidemiológica. A Normas e Manuais Técnicos. Brasília; 2009.

16. Santos AM, Giovanella L, Mendonça MHM, Andrade CLT, Martins MIC, Cunha MS. Práticas assistenciais das Equipes de Saúde da Família em quatro grandes centros urbanos. Ciênc saúde coletiva. 2012;17(10):2687-702.

17. Narchi NZ. Análise do exercício de competências dos não médicos para atenção à maternidade. Saúde Soc. 2010;19(1):147-58.

18. Starfield B. Atenção primária; equilíbrio entre necessidades de saúde, serviços e tecnologia. Brasília: UNESCO, Ministério da Saúde; 2002.

19. Ministério da Saúde (BR). Nota técnica referente à vacinação de gestantes contra hepatite $B$ na rede do SUS. 2010 [acesso 30 abr 2013]. Disponível em: http://portal.saude.gov.br/portal/arquivos/pdf/nota_ tecnica_hepatite007.pdf

20. Kunii M, Milane H. Avaliação de conhecimento, atitude e prática de tocoginecologistas da região de Campinas frente à triagem sorológica de sífilis na gestação e prevenção de sífilis congênita. Campinas; 2010.

21. Leonello VM, Oliveira MAC. Competencies for educational activities in nursing. Rev. Latino-Am. Enfermagem. 2008;16(2):177-83.

22. Silva TAM, Fracolli LA, Chiesa AM. Professional trajectory in the family health strategy: focus on the contribution of specialization programs. Rev. Latino-Am. Enfermagem. 2011;19(1):148-55.

23. Rocha ESB, Nagliate $P$, Furlan CEB, Rocha Jr K, Trevizan MA, Mendes IAC. Knowledge management in health: a systematic literature review. Rev. Latino-Am. Enfermagem. 2012;20(2):392-400. 